\title{
THROMBIN FORMATION. II. EFFECTS OF LYSIN (FIBRINOLYSIN, PLASMIN) ON PROTHROMBIN, AC-GLOBULIN AND TISSUE THROMBOPLASTIN. ${ }^{1}$
}

\author{
By JESSICA H. LEWIS, ANN C. HOWE, AND J. H. FERGUSON
}

(From the Department of Physiology, University of North Carolina, Chapel Hill)

(Received for publication June 30, 1949)

In the course of a study of the blood coagulation reaction involving the use of partially purified reagents it was thought of some interest to determine effects of fibrinolytic enzyme on these isolated materials. It is well known that serum lysin (fibrinolysin, plasmin) will lyse or destroy both fibrinogen and fibrin. It may be thrombinolytic (1). Seegers and Loomis (2) have stated that it destroys prothrombin. In the present study we have compared the effects of lysin on prothrombin, Ac-globulin and tissue thromboplastin.

In choosing a lysin for these studies it was necessary to find a preparation active fibrinolytically but free from thrombin and antithrombin. A preparation of Loomis' (3) fibrinolysin was satisfactory in these respects. Human Fraction III-3 (4) and our dog serum lysin (5) both contained appreciable quantities of thrombin.

\section{MAterials ( $c f .[6])$}

We are indebted to Drs. W. H. Seegers and A. G. Ware (Wayne University, Detroit) for generous supplies of prothrombin and Ac-globulin, and to Dr. E. C. Loomis (Parke, Davis Laboratories) for the fibrinolysin preparation.

Prothrombin (Pro): $0.02 \%$ solution of prothrombin. Lot No. 481203.

Serum accelerator globulin (AcG) : $0.1 \%$ solution of AcG. Lot No. 490215.

Tissue thromboplastin (Tpln) : prepared from acetone dried dog brain. $0.5 \mathrm{gm}$. dried brain was suspended in $50 \mathrm{cc}$. buffer, stirred at $37^{\circ} \mathrm{C}$ for 10 minutes, and centrifuged rapidly for 15 minutes. The supernatant was discarded and the precipitate again suspended in $50 \mathrm{cc}$. buffer, stirred at $37^{\circ} \mathrm{C}$ for 10 minutes and recentrifuged. The supernatant was now passed three times through $5 \mathrm{gms}$. amberlite to remove any calcium, and placed in a boiling water bath for five minutes. The thromboplastin so prepared was quite active and free from fibrinogen, prothrombin, Ac-globulin and calcium.

1 This investigation was supported (in part) by a research grant from the Division of Research Grants and Fellowships of the National Institutes of Health, U. S. Public Health Service.
Fibrinogen $\left(\mathrm{BF}_{2}\right)$ : A $1 \%$ solution of Armour's bovine plasma fraction I was treated by stirring for 10 minutes at $37^{\circ} \mathrm{C}$ with approximately $0.04 \mathrm{gm}$. freshly prepared neutral $\mathrm{BaSO}_{4}$ per cc. of fibrinogen. This absorbed traces of prothrombin, and the insoluble $\mathrm{BaSO}_{*}$ was then removed by centrifugation. This fibrinogen solution was extremely stable at room temperature for a number of days but was routinely prepared in large lots, divided into daily requirements and stored frozen at $-20^{\circ} \mathrm{C}$. Tests on this fibrinogen have shown no clot formed in a week after addition of $\mathrm{Ca}$ or $\mathrm{Ca}+$ thromboplastin.

Thrombin: Thrombin topical, Parke, Davis \& Co., courtesy Dr. E. A. Sharp.

Soybean inhibitor (SBI) : $0.1 \%$ solution of crystalline soybean trypsin-inhibitor obtained through the kindness of Dr. M. Kunitz.

Fibrinolysin (lysin) : $0.5 \%$ solution of Loomis' "profibrinolysin." This material was found to be already active although it had not been treated with chloroform. Shaking with chloroform or incubation, especially at $37^{\circ} \mathrm{C}$, caused decrease in lytic activity.

\section{METHODS}

Methods were presented in detail in a previous report (6). Our standard thrombic activation mixture for this experiment contained $0.5 \mathrm{cc}$. prothrombin, $0.5 \mathrm{cc}$. Acglobulin, $0.5 \mathrm{cc}$. thromboplastin and $0.15 \mathrm{cc}$. molar $\mathrm{CaCl}_{2}$ made up to $5 \mathrm{cc}$. volume with borate buffer. At stated intervals, $0.25 \mathrm{cc}$. of this mixture was added to $0.5 \mathrm{cc}$. of fibrinogen and the clotting time recorded. As the materials used in this experiment differed somewhat from those previously employed, it was necessary to construct a new thrombic activity curve. After full activation, precise dilutions in $\mathrm{Ca}$-buffer were prepared from the control tube, taken as $100 \%$ or 100 units of thrombic activity. A curve similar to that previously presented ([6], Figure 1) was prepared so that thrombic activity of the experimental mixtures could be calculated.

\section{RESULTS}

\section{Preliminary studies on lysin}

The lysin solution was tested for fibrinolytic activity against our standard fibrin clot (7) in the presence and absence of SBI. $0.5 \mathrm{cc}$. of $0.5 \%$ lysin showed moderate fibrinolytic activity (lysis time $=$ five and three-fourths minutes), which 
could be almost completely inhibited by $0.5 \mathrm{cc}$. of $0.1 \%$ soybean inhibitor (lysis time $=$ over four hours).

Lysin, SBI, and buffer were each mixed with equal volumes of a stock thrombin solution. After incubating each mixture at $29^{\circ} \mathrm{C}$ for the stated intervals, $0.25 \mathrm{cc}$. samples were removed and clotting time observed after addition to $0.5 \mathrm{cc}$. fibrinogen. The results are shown in Table I. The clotting times of the thrombin-buffer and

TABLE I

Clotting times by thrombin after mixture with lysin, SBI and buffer

\begin{tabular}{|c|c|c|c|}
\hline & \multicolumn{3}{|c|}{ Incubation at $29^{\circ} \mathrm{C}$} \\
\hline & None & One hour & 24 hours \\
\hline $\begin{array}{l}\text { Lysin } \\
+ \\
\text { Thrombin }\end{array}$ & $13.0^{\prime \prime}$ & $13.0^{\prime \prime}$ & $16.6^{\prime \prime}$ \\
\hline$\stackrel{\text { SBI }}{+}+\underset{\text { Thrombin }}{+}$ & $13.0^{\prime \prime}$ & $13.0^{\prime \prime}$ & $13.2^{\prime \prime}$ \\
\hline $\begin{array}{l}\text { Buffer } \\
+ \\
\text { Thrombin }\end{array}$ & $13.0^{\prime \prime}$ & $12.8^{\prime \prime}$ & $13.0^{\prime \prime}$ \\
\hline
\end{tabular}

thrombin-SBI mixtures did not change in 24 hours. A slight prolongation of clotting time was observed in the thrombin-lysin mixture after 24 hours incubation, suggesting that lysin might be slightly "antithrombic" possibly due to thrombinolysis.

In order to determine whether the lysin contained any thrombin, it was necessary to inhibit the lytic activity so that fibrinogenolysis would not obscure any manifestations of slow clotting. Soybean inhibitor was chosen because its inhibitory action was adequate and it contained no appreciable antithrombin. When added to fibrinogen, lysin alone produced no clot but complete fibrinogenolysis and a lysin-SBI mixture also produced no clot in 48 hours, although adequate fibrinogen remained. Thus, it seemed evident that this particular lysin contained no thrombin.

From these studies we concluded that this lysin preparation was suitable for these experiments as it 1. showed good fibrinolytic activity, 2. produced only minimal thrombin destruction, and 3 . contained no thrombin.

\section{Effects of lysin on prothrombin, Ac-globulin and tissue thromboplastin}

In order to determine the effects of lysin on these materials, the separate ingredients were first incubated with lysin or with buffer and then incorporated into thrombic activation mixtures. 0.5 cc. of buffer (control), Pro, AcG, and Tpln were individually incubated one hour at $29^{\circ} \mathrm{C}$ with either $0.5 \mathrm{cc}$. of buffer or $0.5 \mathrm{cc}$. of lysin. The stock materials were kept in an ice bath during this incubation period and at its termination the specified amounts of materials necessary to complete the mixture and additional buffer to a total volume of $5 \mathrm{cc}$. were added. Thus two groups of activation mixtures were obtained as shown in Table

TABLE II

Composition of thrombic activation mixtures

\begin{tabular}{|c|c|c|c|}
\hline \multicolumn{3}{|c|}{ Preincubation } & \multirow{2}{*}{$\begin{array}{l}\text { Materials added for } \\
\text { thrombic activation }\end{array}$} \\
\hline & Group I & Group II & \\
\hline $\begin{array}{l}\text { Buff } \\
\text { Pro } \\
\text { AcG } \\
\text { Tpln }\end{array}$ & $\begin{array}{l}\text { Buff } \\
\text { Buff } \\
\text { Buff } \\
\text { Buff }\end{array}$ & $\begin{array}{l}\text { Lysin } \\
\text { Lysin } \\
\text { Lysin } \\
\text { Lysin }\end{array}$ & $\begin{array}{l}\text { Pro, AcG, Tpln, Ca } \\
\text { AcG, Tpln, Ca } \\
\text { Pro, Tpln, Ca } \\
\text { Pro, AcG, Ca }\end{array}$ \\
\hline
\end{tabular}

II. These thrombic activation tubes were again incubated at $29^{\circ} \mathrm{C}$ and sampled at intervals to obtain clotting times, which were then converted to units of thrombic activity.

Figure 1 shows graphically the results so obtained. All tubes of the first group, those preincubated with buffer, follow similar activation curves and the same yield of thrombin (100 units) was obtained from each. In contrast to this, the group which contained lysin followed a different pattern with decreased thrombin yield. Thrombin formation in the control for this group and the mixtures in which prothrombin and thromboplastin had each been preincubated with lysin started at a rate similar to the buffer incubated group but the rate soon slowed and the yield was only 55 units after two hours incubation. Additional incubation did not increase the yield. Strikingly different from the other mixtures was that in which Ac-globulin was preincubated with lysin. The rate of thrombin formation was very slow and by two hours only 11 units had been formed. 


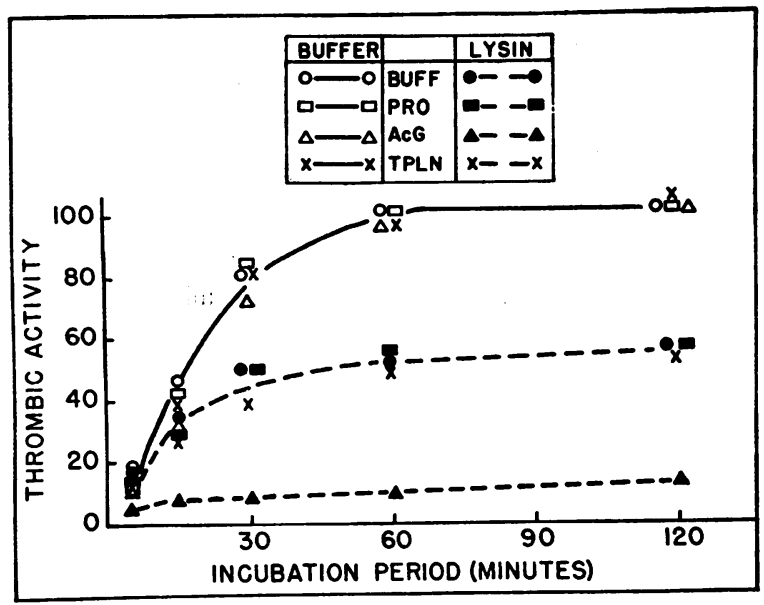

Fig. 1. Thrombin Formation in a Series of Activation Mixtures in Each OF Which a Different Component was Preincubated with either Lysin or BUFFER

Incubation was continued (not shown in Figure 1) and at 24 hours thrombic activity was 14.5 units but by 48 hours thrombin deterioration was evident as only 11 thrombin units remained. A control in which no AcG was added to the thrombic activation mixture showed approximately the same activation curve as the one in which AcG was preincubated with lysin, suggesting that lysin had destroyed most of the added AcG.

The above results were obtained from a single run and illustrate the results found in four similar experiments. The range of results in these experiments showed the buffer incubated group yielding 92-105 units of thrombin after two hours incubation, the lysin incubated group, with the exception of Ac-globulin, yielding 40-55 units of thrombin and the Ac-globulin-lysin incubated tubes, 9-18 units of thrombin. One run was performed in which the lysin and buffer incubations were carried out at $37^{\circ} \mathrm{C}$ for one hour. At this temperature, at which AcG is unstable (6), the Acglobulin-buffer incubated tube yielded only 62 units at two hours while the Ac-globulin-lysin tube yielded 14 units.

\section{DISCUSSION}

In this study we have attempted to determine the effects of lysin on the individual partially purified components of the blood coagulation reac- tion. The well known observation of lysin destruction of fibrin or fibrinogen has been confirmed. Thrombinolysis has been previously shown to occur (1) and we have found some evidence to support this, although the thrombinolytic effects observed were very meager and required long incubation for their manifestation.

Our data show a striking decrease in thrombin yield from the activation mixture containing Acglobulin previously incubated with lysin. We have interpreted this as demonstrating destruction of Ac-globulin by lysin. The yield of thrombin, after a two hour activation period, in the other tubes containing lysin has been about $50 \%$ of the yield in the buffer containing group. The cause of this decreased yield was difficult to determine. We have interpreted it as being due to destruction of the Ac-globulin, added during thrombic activation, and not to previous destruction of the prothrombin or thromboplastin. Two observations suggested this interpretation. The three mixtures containing prothrombin, thromboplastin, or buffer previously incubated with lysin showed similar activation curves. It might be supposed that if either prothrombin or thromboplastin had been partially destroyed by the contact with lysin, an appreciable difference between it and the buffer-lysin control mixture would be detectable. During the first few minutes of thrombic activation the yields obtained from the lysin group were similar to the buffer group, but the rate of thrombin formation soon slowed suggesting that something was being destroyed or inhibited during activation. It seems most likely that the substance destroyed or inhibited was Ac-globulin, although destruction of thrombin during its formation is possible. The latter explanation has not been seriously considered as we were able to find only meager evidence for thrombinolysis (Table I).

\section{CONCLUSIONS}

Certain effects of serum lysin (fibrinolysin, plasmin) on the individual partially purified components of a thrombin forming system were studied. Ac-globulin was readily destroyed by lysin. Prothrombin and thromboplastin were apparently not affected by lysin. Data were obtained which 
suggested that thrombin might be slowly destroyed by lysin. The familiar phenomena of fibrinolysis and fibrinogenolysis were reproduced.

\section{BIBLIOGRAPHY}

1. Ferguson, J. H., Travis, B. L., and Gerheim, E. B., The activation of prothrombin with special reference to "thromboplastic enzyme" (tryptase). Blood, 1948, 3, 1130.

2. Seegers, W. H., and Loomis, E. C., Prothrombin and fibrinolysin. Science, 1946, 104, 461.

3. Loomis, E. C., George, Charles, Jr., and Ryder, Albert, Fibrinolysin: nomenclature, unit, assay, prepara- tion and properties. Arch. of Biochem., 1947, $12,1$.

4. Edsall, J. T., The plasma proteins and their fractionation. Advances in Protein Chemistry, 1947, 8, 383.

5. Lewis, J. H., and Ferguson, J. H., Effects of intravenous injection in dogs of staphylokinase and dog serum lysin. Proc. Soc. Exper. Biol. \& Med., 1949, 71, 677.

6. Lewis, J. H., and Ferguson, J. H., Thrombin formation. I. The role of calcium, serum Ac-globulin and tissue thromboplastin. J. Clin. Invest., 1948, 27, 778.

7. Lewis, J. H., and Ferguson, J. H., Studies on a proteolytic enzyme system of the blood. Federation Proc., 1949, 8, 96. 